\title{
Different toxic effects of YTX in tumor K-562 and lymphoblastoid cell lines
}

\author{
Andrea Fernández-Araujo ${ }^{1}$, Jon A. Sánchez ${ }^{1}$, Amparo Alfonso ${ }^{1}$, Mercedes R. Vieytes ${ }^{2}$ \\ and Luis M. Botana ${ }^{1 *}$ \\ ${ }^{1}$ Department Farmacología, Facultad de Veterinaria, University Santiago de Compostela, Lugo, Spain, ${ }^{2}$ Department \\ Fisiología, Facultad de Veterinaria, University Santiago de Compostela, Lugo, Spain
}

\section{OPEN ACCESS}

Edited by:

Apostolos Zarros,

University of Glasgow, UK

Reviewed by:

Peter James King,

Queen Mary University of London, UK

Christina Elliott,

University of Glasgow, UK

${ }^{*}$ Correspondence:

Luis M. Botana,

Department Farmacología, Facultad de Veterinaria, University Santiago de

Compostela, Carballo Calero Street, 27002 Lugo, Spain luis.botana@usc.es

Specialty section:

This article was submitted to

Experimental Pharmacology and Drug

Discovery

a section of the journa

Frontiers in Pharmacology

Received: 23 January 2015

Accepted: 01 June 2015

Published: 17 June 2015

Citation:

Fernández-Araujo A, Sánchez JA Alfonso A, Vieytes MR and Botana LM (2015) Different toxic effects of YTX in tumor K-562 and lymphoblastoid cell lines. Front. Pharmacol. 6:124. doi: 10.3389/fphar.2015.00124
Yessotoxin (YTX) modulates cellular phosphodiesterases (PDEs). In this regard, opposite effects had been described in the tumor model K-562 cell line and fresh human lymphocytes in terms of cell viability, cyclic adenosine 3',5'-cyclic monophosphate (CAMP) production and protein expression after YTX treatment. Studies in depth of the pathways activated by YTX in K-562 cell line, have demonstrated the activation of two different cell death types, apoptosis, and autophagy after 24 and $48 \mathrm{~h}$ of treatment, respectively. Furthermore, the key role of type 4A PDE (PDE4A) in both pathways activated by YTX was demonstrated. Therefore, taking into account the differences between cellular lines and fresh cells, a study of cell death pathways activated by YTX in a non-tumor cell line with mitotic activity, was performed. The cellular model used was the lymphoblastoid cell line that represents a non-tumor model with normal apoptotic and mitotic machinery. In this context, cell viability and cell proliferation, expression of proteins involved in cell death activated by YTX and mitochondrial mass, were studied after the incubation with the toxin. Opposite to the tumor model, no cell death activation was observed in lymphoblastoid cell line in the presence of YTX. In this sense, variations in apoptosis hallmarks were not detected in the lymphoblastoid cell line after YTX incubation, whereas this type I of programmed cell death was observed in K-562 cells. On the other hand, autophagy cell death was triggered in this cellular line, while other autophagic process is suggested in lymphoblastoid cells. These YTX effects are related to PDE4A in both cellular lines. In addition, while cell death is triggered in $\mathrm{K}-562$ cells after YTX treatment, in lymphoblastoid cells the toxin stops cellular proliferation. These results point to YTX as a specific toxic compound of tumor cells, since in the non-tumor lymphoblastoid cell line, no cell death hallmarks are observed.

\section{Keywords: Yessotoxin, apoptosis, autophagy, K-562, lymphoblastoid line}

\section{Introduction}

Under unfavorable conditions, cells develop different strategies to survive and autophagy is the main mechanism; if survival is not possible, they activate autophagy cell death (Codogno and Meijer, 2005). Autophagy, also known as type II programmed cell death is activated after nutrient deprivation or with other stimulus, such as rapamycin treatment (Jung et al., 2010; Ouyang et al., 2012). In both cases, the target is the protein mTOR. This protein inhibits the autophagy through its active phosphorylated form (pmTOR). Under unfavorable conditions, the protein is dephosphorylated and inactivated, and as a result the autophagy cascade is triggered 
(Jung et al., 2010). Then, a complex network of metabolic pathways is activated to develop digestive vacuoles, called autophagosomes. These vacuoles are covered by type II of Light Chain 3 (LC3-II) protein (Codogno and Meijer, 2005; Stern et al., 2012). Three different human isoforms are described of LC3 protein: LC3A, LC3B, and LC3C (Wu et al., 2006). These types of LC3 protein are synthesized as the cytosolic type I LC3 protein (LC3A-I, LC3B-I, or LC3C-I) under normal conditions. When autophagy is activated, LC3-I is metabolized in type II (LC3A-II, LC3B-II, or LC3C-II) that binds to autophagosomes membrane (Lazova et al., 2012). Different parts of the cell and damaged organelles are digested by autophagosomes and fused with lysosomes (Klionsky and Emr, 2000). In this way, the basic elements to survive under unfavorable conditions are obtained (Cuervo et al., 2005). However, sometimes, autophagy degenerates in the digestion of the whole cell leading to the autophagy cell death (Tsujimoto and Shimizu, 2005). Another type of programmed cell death is apoptosis, also known as the type I of programmed cell death (Ouyang et al., 2012). Apoptosis can be activated through the intrinsic or mitochondrial apoptotic cell death or through the extrinsic or death receptor (DR) pathway (Elmore, 2007). The first one, known as mitochondrial apoptosis, is triggered by different stimulus that destabilizes mitochondrial membrane potential. As a result, the mitochondrial permeability transition pore (MPTP) is opened and pro-apoptotic proteins are released from the intermembrane space to the cytosol (Debatin et al., 2002). The pro-apoptotic proteins such as cytochrome c, smac/DIABLO, apoptotic inductor factor (AIF), and endonuclease G, activate first caspase 9 and then caspase 3 along with the rest of the apoptotic pathway (Javadov and Karmazyn, 2007). The extrinsic apoptotic cell death is triggered after the binding of a ligand to the DR that belongs to the tumor necrosis factor receptor family (TNFR), in the plasmatic membrane. Then, the death inducing signaling complex (DISC) is developed in the cytosolic region of the plasma membrane. This complex recruits and cleaves procaspases 8 and 10 into the active forms caspases 8 and 10 . Caspase 8 also activates caspase 3 and converges at this point with the intrinsic apoptotic pathway (Korsnes and Espenes, 2011).

Yessotoxins (YTXs) are sulfated polyether compounds isolated for the first time from the scallops Patinopecten yessoensis (Murata et al., 1987). However, this group of toxins are synthesized by the dinoflagellates Protoceratium reticulatum, Lingulodinium polyedrum, and Gonyaulax spinifera (Satake et al., 1997; Paz et al., 2004; Rhodes et al., 2006). YTXs are modulators of phosphodiesterases (PDEs) and consequently affect the levels of cyclic adenosine $3^{\prime}, 5^{\prime}$-cyclic monophosphate (cAMP) (Alfonso et al., 2003, 2004, 2005; Pazos et al., 2006). The final effect is different depending on the cellular model studied, human fresh lymphocytes or human leukemic K-562 cell line (Alfonso et al., 2003; Tobío et al., 2012). Moreover, YTX has been described as a mitochondrial apoptosis inducer (Korsnes and Espenes, 2011; Korsnes, 2012). On the other hand, the structural protein A kinase anchoring protein 149 (AKAP149) binds PDE4A and protein kinase A (PKA) to the outer mitochondrial membrane (Asirvatham et al., 2004; Carlucci et al., 2008). These three components make a complex that is regulated by cAMP levels, since this second messenger activates PKA, and the whole complex moves around the cell depending on cAMP gradients (Baillie et al., 2005; Sample et al., 2012). Since YTX modulates PDEs, the complex was studied after toxin treatment in the tumor $\mathrm{K}-562$ cell line. In this sense, a close relation between the complex expression and cell death activated by the toxin was discovered (Tobío et al., 2012; Fernandez-Araujo et al., 2014). This was supported by the fact that silencing the expression of PDE4A, the effect of YTX on K-562 cell viability is avoided and changes in the cytosolic expression of the rest of the proteins of the complex is observed (Fernandez-Araujo et al., 2014). In addition, a key role of PDE4A in apoptosis and autophagy cell death activated by YTX in the K-562 cell line has been observed (FernándezAraujo et al., 2015). As mentioned, large differences, in terms of YTX toxicity, cAMP levels and AKAP149 expression, were found depending on the cellular model studied. In this sense, while no effect on cell viability was observed in human fresh lymphocytes, high cell death was detected in leukemic K-562 cells after YTX treatment (Tobío et al., 2012). Later on, the effect in the K-562 line was studied in depth and YTX was described as apoptotic and autophagy inductor in these cells (Fernandez-Araujo et al., 2014). As fresh lymphocytes have no mitotic capacity while leukemia cells are tumor cells, the aim of this work was to study the effect of YTX in a non-tumor cellular model with mitotic and apoptotic intact machinery in order to elucidate whether the toxic effects of YTX are exclusively for tumor cells or if they depend on the mitotic machinery. For this objective a non-tumor cell line, a lymphoblastoid cell line, was chosen. This cell line is a result of human B lymphocytes immortalized with the Epstein Barr virus, hence without tumor features (Sugimoto et al., 2004; Sie et al., 2009; Hussain and Mulherkar, 2012).

\section{Materials and Methods}

\section{Reagents and Solutions}

YTX was obtained from CIFGA Laboratories (Lugo, Spain). Anti- $\beta$-tubulin I, Bovine serum albumin (BSA), $\mathrm{CaCl}_{2}$, $\mathrm{NaH}_{2} \mathrm{PO}_{4}$, Trizma hydrochloride, Triton X-100, glycine, trizma base, SDS (sodium dodecyl sulfate) and Tween ${ }^{\circledR} 20$ were from Sigma-Aldrich (Madrid, Spain). $\mathrm{NaCl}, \mathrm{MgSO}_{4}, \mathrm{NaHCO}_{3}$, and glucose were from Panreac (Barcelona, Spain). Anti-PDE4A and anti-LC3B was from ABCAM (CA, USA). Anti-Histone 1 , anti- $\beta$-Actin, anti-pmTOR, anti-caspase 8 (active form), anti-cytochrome $\mathrm{C}$, anti-rabbit IgG peroxidase conjugated, and Polyvinylidene fluoride (PVDF) membrane was from Millipore (Temecula, USA). Anti-Mouse IgG horseradish peroxidaselinked species-specific whole antibody was purchased from GE Healthcare (Barcelona, Spain).

Polyacrylamide gels and molecular weight marker Precision Plus Protein ${ }^{\mathrm{TM}}$ Standards Kaleidoscope ${ }^{\mathrm{TM}}$ were purchased from BioRad $^{\circledR}$ (Barcelona, Spain). Protease Inhibitor Complete Tablets and Phosphatase Inhibitor Cocktail Tablets were from Roche (Spain). Free calcium and magnesium PBS used in flow cytometry assays was purchased from Gibco, Life Technologies (UK).

Physiological saline solution composition was (in mM): $\mathrm{Na}^{+}$ 142.3; $\mathrm{K}^{+}$5.94; $\mathrm{Ca}^{2+} 1 ; \mathrm{Mg}^{2+} 1.2 ; \mathrm{Cl}^{-} 126.2 ; \mathrm{HCO}_{3}^{-} 22.85$; 
$\mathrm{HPO}_{4}^{2-} 1.2, \mathrm{SO}_{4}^{2-} 1.2$; glucose $1 \mathrm{~g} / \mathrm{L}$ was added to the medium giving an osmotic pressure of $290 \pm 10 \mathrm{mOsm} / \mathrm{kg}$ of $\mathrm{H}_{2} \mathrm{O}$ and $\mathrm{pH}$ was adjusted to 7.2 with $\mathrm{HCl} 0.1 \mathrm{~N}$ and $\mathrm{CO}_{2}$. PBS used to wash the western blotting membranes consisted of $\mathrm{NaCl} 137 \mathrm{mM}$; $\mathrm{Na}_{2} \mathrm{HPO}_{4} 10.14 \mathrm{mM} ; \mathrm{KH}_{2} \mathrm{PO}_{4} 1.76 \mathrm{mM} ; \mathrm{KCl} 2.68 \mathrm{mM}$; pH was adjusted to 7.2 with $\mathrm{NaOH}$.

\section{Cell Culture}

K-562 cell line was purchased from the National Cancer Institute (NCI's, USA) and maintained in the Roswell Park Memorial Institute 1640 (RPMI 1640) medium supplemented with $10 \%$ fetal bovine serum (FBS) and $50 \mathrm{units} / \mathrm{ml}$ penicillin and $50 \mu \mathrm{g} / \mathrm{ml}$ streptomycin. All these reagents were from Gibco, Invitrogen (Spain). Cells were growing at $37^{\circ} \mathrm{C}$ in a humidified $5 \% \mathrm{CO}_{2}$ atmosphere. Incubations with $30 \mathrm{nM}$ YTX were carried out under these conditions of temperature, humidity and percentage of $\mathrm{CO}_{2}$.

Lymphoblastoid cell line was obtained from the Banco Nacional de ADN Carlos III (Spain). This cell line is a result of human B lymphocytes immortalized with the Epstein Barr virus, without tumor features and can be used for genetic or functional studies since these cells preserve the genetic characteristics of the lymphocyte B donor (Sugimoto et al., 2004; Sie et al., 2009; Hussain and Mulherkar, 2012). Lymphoblastoid cell line is maintained in the Roswell Park Memorial Institute 1640 (RPMI 1640) medium with HEPES and glutamine (from Biowest, France), supplemented with $15 \%$ fetal bovine serum (FBS), 100 units/ml penicillin and $100 \mu \mathrm{g} / \mathrm{ml}$ streptomycin. All these reagents were from Gibco (Invitrogen, Spain). Cells were growing at $37^{\circ} \mathrm{C}$ in a humidified $5 \% \quad \mathrm{CO}_{2}$ atmosphere. Incubations with $30 \mathrm{nM}$ YTX were carried out under these conditions of temperature, humidity, and percentage of $\mathrm{CO}_{2}$.

\section{Subcellular Fractionation}

$3 \times 10^{6}$ cells per condition were incubated for 24 and $48 \mathrm{~h}$ with and without $30 \mathrm{nM}$ YTX and then centrifuged and washed with saline solution. Cells were resuspended in lysis buffer with the following composition: $50 \mathrm{mM}$ Tris- $\mathrm{HCl}, 150 \mathrm{mM} \mathrm{NaCl}, 1 \mathrm{mM}$ EDTA, 1\% Triton X-100, 1X Complete Protease Inhibitor and 1X Phosphatase Inhibitor Cocktail. The extract was sonicated and centrifuged (9300 g, $10 \mathrm{~min}, 4^{\circ} \mathrm{C}$ ). The supernatant with the cytosolic fraction was transferred to a new tube and stored at $-20^{\circ} \mathrm{C}$ for protein quantification.

\section{Western Blotting Analysis}

Direct Detect Spectrometer from Millipore (Germany) was used to know sample protein concentration and BSA was used as protein standard. The electrophoresis run conditions were $200 \mathrm{~V}$ for $35 \mathrm{~min}$. The cytosolic fraction was blotted to PVDF membrane with reduced SDS-PAGE. To determine the protein size and also to monitor the progress of the electrophoretic runs, a Precision Plus ProteinTM Standards Kaleidoscope ${ }^{\mathrm{TM}}$ molecular weight marker was used. After blockage with $0.5 \%$ BSA the membranes were incubated for $10 \mathrm{~min}$ with anti-cytochrome $\mathrm{C}$, anti-PDE4A, anti-caspase 8 , and anti-pmTOR, then were washed three times with PBS and $0.1 \%$ Tween ${ }^{\circledR} 20$ and incubated for $10 \mathrm{~min}$ with secondary anti-mouse or anti-rabbit IgG horseradish peroxidase-linked species-specific whole antibody. After three washes, chemiluminescence was visualized with SuperSignal ${ }^{\circledR}$ West Pico (low intensity) or with SuperSignal ${ }^{\circledR}$ West Femto (high intensity) both from Pierce (ThermoScientific, USA) and it was also used a Clarity Western ECL substrate (medium intensity) from BioRad $^{\circledR}$. The chemiluminiscent signal was detected with the Diversity GeneSnap software and analyzed by the Diversity 4 gel documentation and analysis system. Relative protein expression was calculated in relation to $\beta$ actin expression for each experiment in the cytosolic fraction. Experiments were carried out at least three times by duplicate. The purity of the subcellular fraction was tested by measuring control proteins from the cytosol fraction: Histone 1 was the negative control, as it is only present in the nuclear fraction and $\beta$-tubulin was the positive control because it is located in the cytosolic fraction.

\section{Cell Viability}

After the treatment with the toxin, $5 \times 10^{5}$ cells per condition, cells were centrifuged $\left(250 \times \mathrm{g}, 4 \mathrm{~min}, 4^{\circ} \mathrm{C}\right)$ and pellet and supernatant were separated. The pellets were first washed with saline solution and centrifuged $\left(1100 \times \mathrm{g}, 5 \mathrm{~min}, 4^{\circ} \mathrm{C}\right)$, and then re-suspended in saline solution with MTT $(250 \mu \mathrm{g} / \mathrm{mL})(\mathrm{M} 2128$, Sigma) and incubated for cell viability (Tobío et al., 2012). The supernatants were utilized to measure $\mathrm{LDH}$ release by using the in vitro Toxicology Assay Kit (TOX7, Sigma) following the commercial protocol.

\section{Mitochondrial Mass}

After the treatment with the toxin, cells were washed with saline solution, centrifuged $\left(1200 \times \mathrm{g}, 5 \mathrm{~min}, 4^{\circ} \mathrm{C}\right)$ and incubated with $200 \mathrm{nM}$ MitoTracker ${ }^{\circledR}$ Deep Reed FM (Invitrogen, USA) for $30 \mathrm{~min}$, at $37^{\circ} \mathrm{C}$ in dark. Then the cells were washed and fixed with $4 \%$ paraformaldehyde (PFA) for $20 \mathrm{~min}$ at $4^{\circ} \mathrm{C}$. Next, the cells were washed twice with PBS free of calcium and magnesium and finally resuspended in $80 \mu \mathrm{L}$ PBS for flow cytometry. The data were analyzed with the IDEAS 4.0 Cell Image Analysis software. The assays were performed with $1 \times 10^{6}$ cells per condition.

\section{Cell Proliferation}

Cell proliferation was measured by using three methods, the Scepter $^{\mathrm{TM}}$ Handheld automated cell counter (Millipore, Spain) and two methods for total cellular protein determination, Bradford (Bio-Rad protein Assay) and the Direct Detect ${ }^{\mathrm{TM}}$ Spectrometer (Millipore, Germany). The number of cells was corrected in each experiment with the cell viability data by using the MTT assay. After the treatment with $30 \mathrm{nM}$ of YTX for 24 and $48 \mathrm{~h}, 6 \times 10^{5}$ cells per condition, cells were centrifuged $(600 \times \mathrm{g}$, $5 \mathrm{~min}, 4^{\circ} \mathrm{C}$ ), and supernatants were eliminated. The pellets were first washed with saline solution and centrifuged $(600 \times \mathrm{g}$, $5 \mathrm{~min}, 4^{\circ} \mathrm{C}$ ), and then re-suspended in saline solution $250 \mu \mathrm{L}$. Hundred microliter of cellular suspension were used to count the number of cells with the Scepter ${ }^{\mathrm{TM}}$ Handheld automated cell counter. One hundred and fifty microliter were centrifuged, diluted in $50 \mu \mathrm{l}$ of water and sonicated. Then, the concentration of protein was determined both, by Bradford assay and Direct 
Detect $^{\mathrm{TM}}$ (Millipore, Spain). A calibration curve of number of cells $(750,000$ from 50,000$)$ vs. concentration of protein was done in each experiment and the linearity was always higher than 0.99 for both cellular lines.

\section{Statistical Analysis}

All the experiments were carried out at least three times by duplicate. ANOVA was used to examine statistical significance, assumed for $p<0.05$. Results were expressed as the means \pm SEM.

\section{Results}

Opposite effects of YTX were reported in tumor K-562 cell line and fresh human lymphocytes (Tobío et al., 2012). This may be due to the differences between these cellular models, since fresh human lymphocytes do not have the ability to grow by themselves. Therefore, it would be interesting to compare the effect of YTX in two cellular lines with similar mitotic machinery. For this purpose, the lymphoblastoid cell line was chosen as a non-tumor model, and compared with the K-562 tumor cell line model. The lymphoblastoid cell line can grow and has normal apoptotic machinery, while the K-562 cell line has not (Hussain and Mulherkar, 2012). Figure 1 shows cellular proliferation, measured by MTT metabolization, and plasma membrane integrity measured by LDH release (Figures $\mathbf{1 A , B}$, respectively) in both cell lines after 24 and $48 \mathrm{~h}$ of toxin exposure. A $32 \%$ decrease in cell viability was observed in K-562 cell line after $24 \mathrm{~h}$ with YTX. However, no effect was observed in lymphoblastoid line under the same conditions. After $48 \mathrm{~h}$ of treatment, K-562 cell viability was decreased by $59 \%$ while the reduction in lymphoblastoid cell line was $27 \%$. On the other hand, after $24 \mathrm{~h}$ of YTX treatment, LDH release was $78 \%$ increased in the K-562 cell line, while at this time YTX did not induce any effect in LDH release in lymphoblastoid cells. After $48 \mathrm{~h}$ in the presence of YTX, the increase in LDH release was $52 \%$ in K-562 cells, while no effects were observed in lymphoblastoid cells.

The result obtained after $48 \mathrm{~h}$ of YTX treatment in lymphoblastoid cells with MTT, show a decrease in cellular proliferation but not in LDH release. Since the MTT dye is metabolized by the mitochondria, the fall of MTT signal observed may be caused either by a decrease in mitochondrial mass or by a decrease in the cell number. To find out which of the two options was going on, a dye to measure mitochondrial mass was used and in this way to know the direct effect of YTX in this organelle by using imaging flow cytometry. Therefore, in Figure 2 mitochondrial mass is shown both in K-562 cell line and in lymphoblastoid line. When the MitoTracker ${ }^{\circledR}$ Deep Reed FM dye is metabolized by the mitochondria, the intensity in red channel is increased, therefore this signal is proportional to mitochondria quantity. Figures $2 \mathbf{A}, \mathbf{B}$ represent mitochondrial mass of K-562 cells and lymphoblastoid cells, respectively, after $48 \mathrm{~h}$ of YTX incubation. Higher X-axis values represent more dye intensity, hence more quantity of the mitochondria. Figure $\mathbf{2 C}$ represents the mean of three experiments. This graphic shows a significant $6 \%$ decrease of mitochondrial intensity after $48 \mathrm{~h}$ of

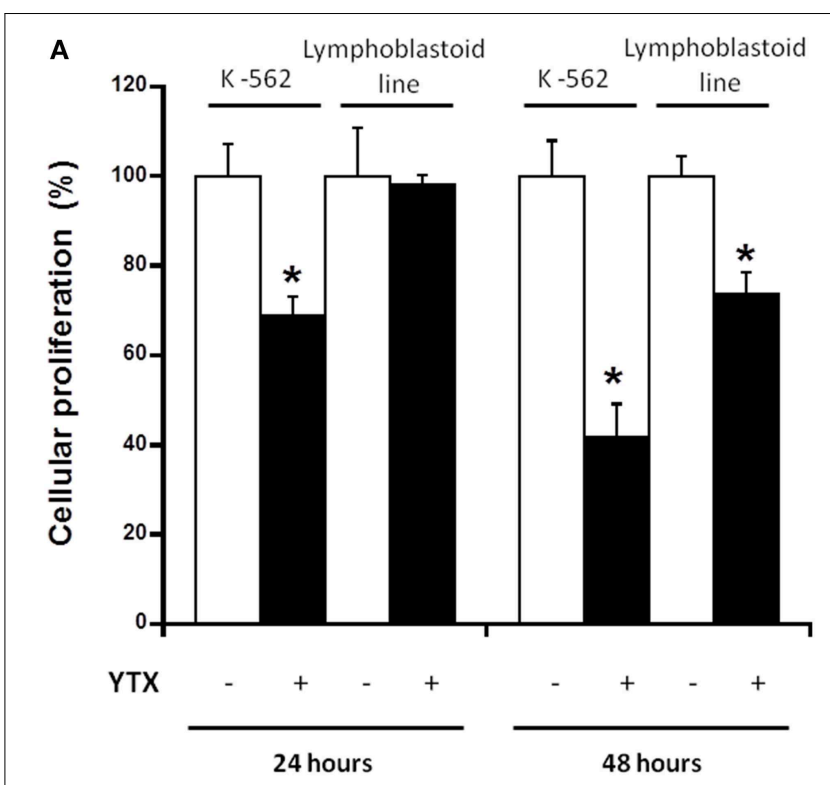

B

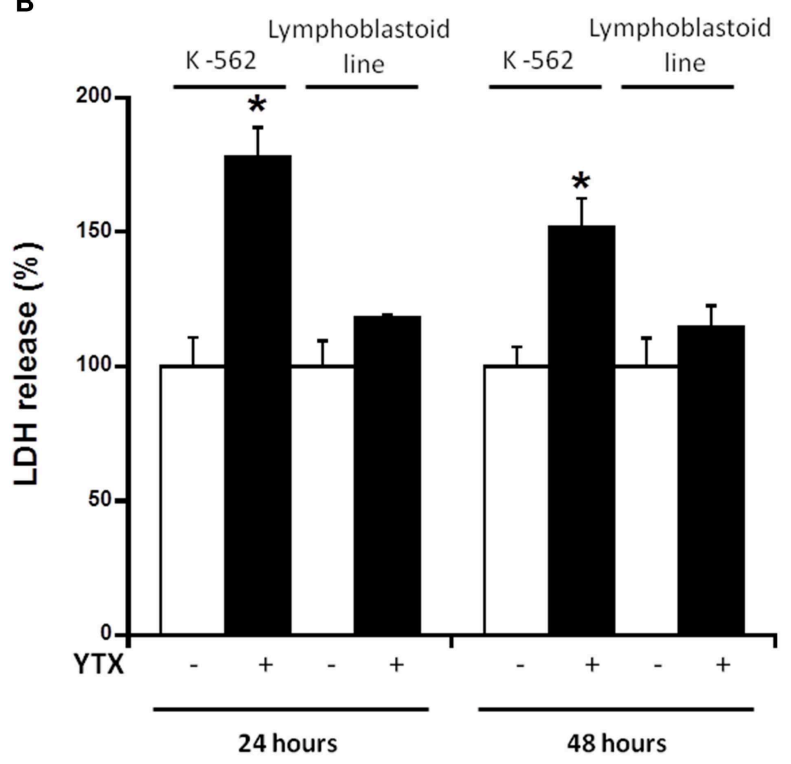

FIGURE 1 | Effect of YTX on cellular MTT signal and LDH release in K-562 and lymphoblastoid cell lines. Cells were incubated with $30 \mathrm{nM}$ YTX for 24 and $48 \mathrm{~h}\left(37^{\circ} \mathrm{C}\right.$ and $5 \% \mathrm{CO}_{2}$ atmosphere). (A) Percentage of cellular proliferation measured by MTT assay in K-562 and lymphoblastoid cell lines after 24 and $48 \mathrm{~h}$ of YTX incubation. (B) Percentage of LDH release of K-562 and lymphoblastoid cell lines after 24 and $48 \mathrm{~h}$ of YTX incubation. Mean \pm SEM of three experiments. *Significant differences between untreated and YTX-treated cells in each case by ANOVA test.

incubation with YTX in a K-562 cell line, while the intensity is $9 \%$ increased in the lymphoblastoid line. Therefore, the decrease in MTT signal obtained in Figure 1A with the lymphoblastoid line after $48 \mathrm{~h}$ of treatment with YTX is probably not due to a decrease in mitochondrial mass but probably due to a decrease in the cell number with respect to the control without treatment.

It has been described the key role of PDE4A in the mechanism of action of YTX (Fernandez-Araujo et al., 2014). Therefore, 

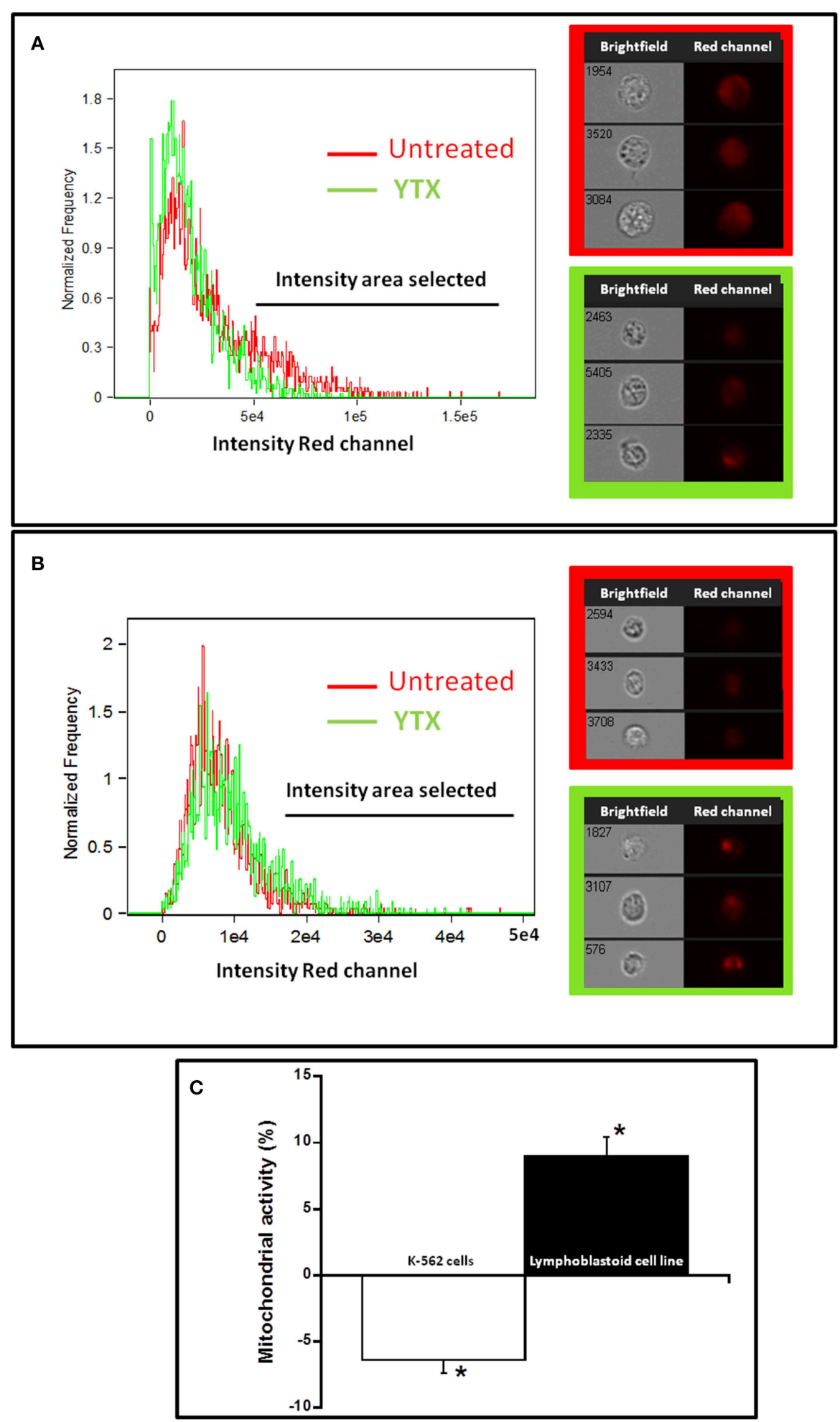

FIGURE 2 | Effect of YTX on total mitochondrial mass of K-562 and lymphoblastoid cell lines. Representative cellular images and histograms of the mitochondrial mass intensities in K-562 and lymphoblastoid cell lines after $48 \mathrm{~h}$ (A,B, respectively) of YTX incubation $\left(37^{\circ} \mathrm{C}\right.$ and $5 \% \mathrm{CO}_{2}$ atmosphere). Brightfield images and red channel images with MitoTracker ${ }^{\circledR}$ Deep Reed FM intensity are represented to each cell model on the right of the histograms. (C) Percentage of cells with mitochondrial mass intensities selected of K-562 and lymphoblastoid cell lines after $48 \mathrm{~h}$ of YTX treatment. Data referred to untreated cells. Mean \pm SEM of three experiments (5000 cells were analyzed in each experiment). *Significant differences between YTX-treated and untreated cells by ANOVA test. 
this protein was studied in the lymphoblastoid cell line and compared to the tumor K-562 cell line after YTX treatment. Figure 3 shows the PDE4A expression in both cell models after 24 and $48 \mathrm{~h}$ (Figures 3A,D, respectively) of exposure to the toxin. While a 25\% decrease in PDE4A expression was observed in $\mathrm{K}$ 562 cells after $24 \mathrm{~h}$ of treatment, no variations were detected in the lymphoblastoid cell line (Figure 3A). However, as Figure 3D shows, a decrease of 34 and 22\%, in PDE4A levels was observed in K-562 and lymphoblastoid lines, respectively, after $48 \mathrm{~h}$ of toxin treatment. Therefore, cytosolic PDE4A levels are also involved in YTX effect in lymphoblastoid cell line. Surprisingly, according to the western blot experiments, different molecular weights for PDE4A proteins were observed depending on cellular model use. Figure 3G shows the PDE4A band with a lower molecular weight, around $80 \mathrm{KDa}$, in the case of K-562 cells, and 98 $\mathrm{KDa}$ band in lymphoblastoid cells. This is the normal molecular weight that targets the anti-PDE4A used in these experiments.

Either, the activation of both intrinsic and extrinsic apoptosis processes through PDE4A modulation in K-562 cells after $24 \mathrm{~h}$ YTX incubation, as well as the autophagy cell death triggered through the PDE4A modulation in the same cell line after $48 \mathrm{~h}$ of YTX treatment were extensively studied (FernandezAraujo et al., 2014; Fernández-Araujo et al., 2015). Therefore, the activation of these pathways was checked in the lymphoblastoid cell line. First, different apoptotic hallmarks were studied under these conditions. Figure 4 shows the expression of the mitochondrial apoptotic marker cytochrome c. While in the K562 cell line a 34\% increase in cytosolic cytochrome c levels after $24 \mathrm{~h}$ YTX incubation, no effects were observed in lymphoblastoid cells. The same happens when the typical extrinsic apoptotic hallmark, the active form of caspase 8, was measured. As Figure 5 shows, caspase 8 levels were $75 \%$ increased in the tumor K-562 cell line in the presence of YTX for $24 \mathrm{~h}$, while in these conditions no effect was observed in the lymphoblastoid line. Therefore, contrary to K-562 cell line, after $24 \mathrm{~h}$ of incubation in the presence of YTX apoptosis was not activated in the lymphoblastoid cell line. Since autophagy was trigged in the K-562 cell line after $48 \mathrm{~h}$ of YTX incubation, next the active form of mTOR (pmTOR), as one representative autophagy hallmark, was checked in the lymphoblastoid cell line after $48 \mathrm{~h}$ incubation with the toxin (Codogno and Meijer, 2005). Surprisingly, similar results were obtained in both K-562 and lymphoblastoid cell lines. A decrease of 39 and $40 \%$ was observed after $48 \mathrm{~h}$ of YTX treatment in the tumor and in the non-tumor cell line, respectively (Figure 6). Furthermore, Figure 7 shows the other autophagic hallmark studied in both cell lines, the LC3B-II/LC3B-I ratio. Again very similar results were obtained in both cellular models, since after $48 \mathrm{~h}$ of YTX incubation an increase of $208 \%$ in LC3B-II/LC3B-I ratio was observed in K-562 cells and 190\% in lymphoblastoid cell line. Therefore, these results suggest the activation of an autophagic pathway in the lymphoblastoid cell line, but it does not imply the induction of cell death since no $\mathrm{LDH}$ release was observed as Figure 1B shows. However, to confirm this theory, the proliferation of both cell lines was studied, Figure 8. K-562 cells grow up from near to $6 \times 10^{5}$ cells at the beginning of the experiment, time 0 , to around $7.3 \times 10^{5}$ after $24 \mathrm{~h}$ and to around of $11 \times 10^{5}$ after $48 \mathrm{~h}$ (Figure 8A). However, after $24 \mathrm{~h}$ of YTX

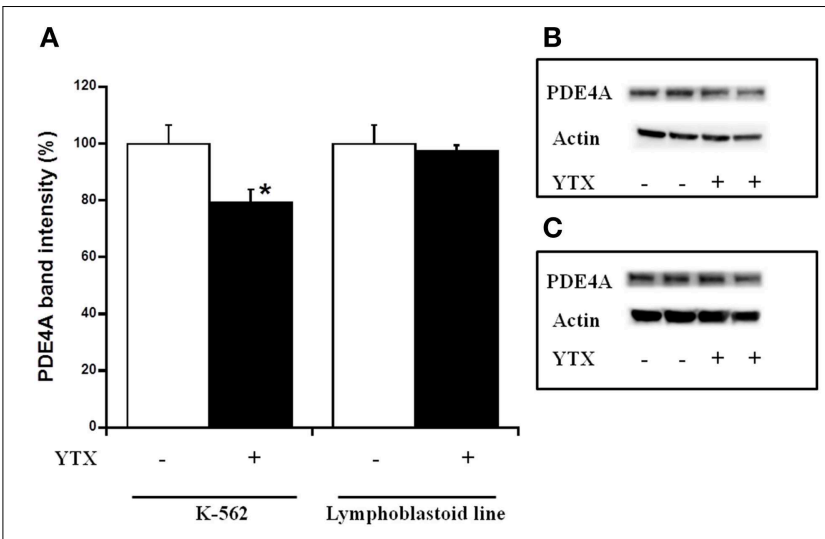

D $\quad$ E

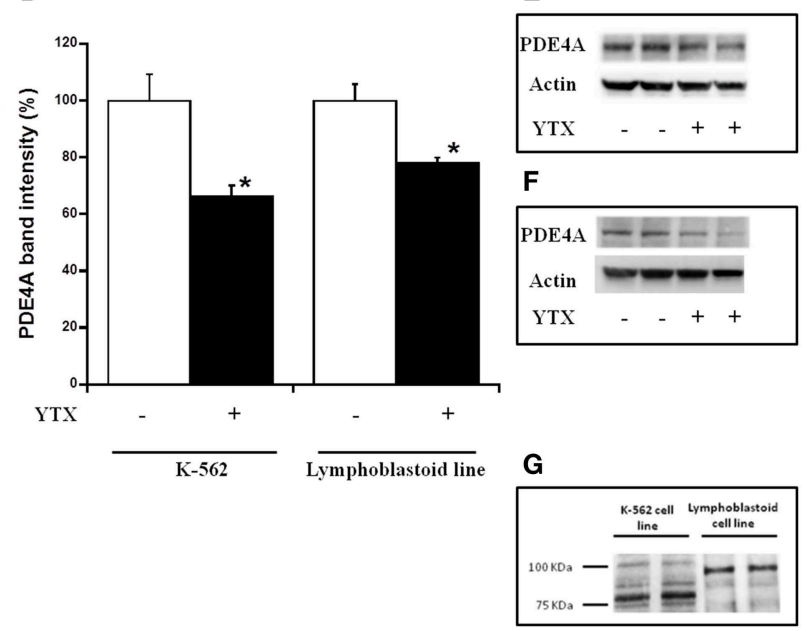

FIGURE 3 | Effect of YTX on cytosolic PDE4A expression in K-562 and lymphoblastoid cell. Cells were incubated for 24 and $48 \mathrm{~h}$ with $30 \mathrm{nM}$ YTX $\left(37^{\circ} \mathrm{C}\right.$ and $5 \% \mathrm{CO}_{2}$ atmosphere). (A,D) Percentage of cytosolic PDE4A levels in K-562 and lymphoblastoid cell lines after 24 and $48 \mathrm{~h}$ of YTX incubation, respectively. Mean \pm SEM of three experiments. Cytosolic PDE4A values were calculated respect to $\beta$-actin band intensity. $3 \times 10^{6}$ cells per condition were lysed and $20 \mu \mathrm{g}$ of total protein per condition was charged in the electrophoresis gel. *Significant differences between untreated and YTX-treated cells by ANOVA test. (B,C) Representative experiments of western blot band intensity of cytosolic PDE4A in K-562 ( $\sim 0 \mathrm{KDa})$ and lymphoblastoid ( $\sim 98 \mathrm{KDa}$ ) cell lines after $24 \mathrm{~h}$ of treatment, respectively. (E,F) Representative experiments of western blot band intensity of cytosolic PDE4A in K-562 ( $80 \mathrm{KDa})$ and lymphoblastoid ( 98 KDa) cell lines after $48 \mathrm{~h}$ of treatment, respectively. (G) PDE4A band of K-562 and lymphoblastoid cell lines in western blot membranes. PDE4A antibody targets to a PDE4A protein with a molecular weight of $98 \mathrm{KDa}$.

incubation, the number of cells has decreased to $4.7 \times 10^{5}$ cells, and after $48 \mathrm{~h}$ of YTX treatment, the number of cells has fallen to near $3.7 \times 10^{5}$ cells. These results mean a decrease in cells number after YTX incubation and significant differences were obtained in untreated and YTX-treated cells. On the other hand, lymphoblasoid cell line shows another pattern of proliferation (Figure 8B). The total number of cells in control population was around $5.6 \times 10^{5}, 7.4 \times 10^{5}$, and $9 \times 10^{5}$ at time 0 , after 24 and $48 \mathrm{~h}$, respectively. However, after $24 \mathrm{~h}$ of YTX treatment, the number of cells was near to $6.64 \times 10^{5}$, and after $48 \mathrm{~h}$ of 


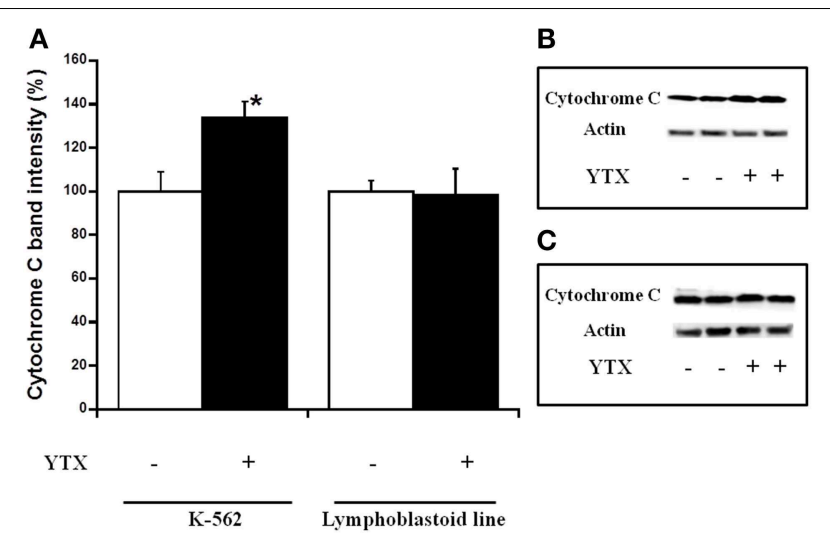

FIGURE 4 | Effect of YTX on cytosolic cytochrome c expression in K-562 and lymphoblastoid cell lines after $\mathbf{2 4} \mathbf{h}$ of incubation. Cells were incubated for $24 \mathrm{~h}$ with $30 \mathrm{nM}$ YTX $\left(37^{\circ} \mathrm{C}\right.$ and $5 \% \mathrm{CO}_{2}$ atmosphere). (A) Percentage of cytosolic cytochrome c levels in K-562 and lymphoblastoid cell lines after $24 \mathrm{~h}$ of YTX incubation. Mean \pm SEM of three experiments. Cytosolic cytochrome $\mathrm{c}$ values were calculated respect to $\beta$-actin band intensity. $3 \times 10^{6}$ cells per condition were lysed and $20 \mu \mathrm{g}$ of total protein per condition was charged in the electrophoresis gel. *Significant differences between untreated and YTX-treated cells by ANOVA test. (B,C) Representative experiments of western blot band intensity of cytosolic cytochrome c in K-562 and lymphoblastoid cell lines after $24 \mathrm{~h}$ of treatment, respectively.

YTX incubation, the number of cells was around $5.5 \times 10^{5}$. No significant differences in the number of cells were observed after 24 and $48 \mathrm{~h}$ of YTX treatment compared to time 0 , therefore neither cell death nor growth was detected. Also, no differences were detected between untreated and YTX-treated cells after $24 \mathrm{~h}$ of YTX incubation. However, the number of cells after $48 \mathrm{~h}$ of YTX treatment was significantly lower compared to untreated cells at this time. Therefore, the proliferation of lymphoblastoid cell line was arrested by YTX effect.

\section{Discussion}

YTX activates different cell death types depending on the cellular model (Korsnes, 2012). Moreover, opposite effects in terms of cell viability were obtained after the treatment with YTX of the tumor K-562 cell line and fresh human lymphocytes (Tobío et al., 2012). These observations point to YTX as an interesting compound to target tumor cell lines but not normal cells (Botana et al., 2011). However, there are several differences between an immortalized cellular line and fresh primary cells (Baserga, 1965). In this context, the comparative study of YTX effect in a tumor cell line and a non-tumor cell line could give interesting information about the mechanism of action of YTX. The pathways activated in the leukemic K-562 cell line by this toxin were widely studied. It was described that PDE4A shows a key role in YTX effect that leads to the activation of different programmed cell death types (Tobío et al., 2012; Fernandez-Araujo et al., 2014; FernándezAraujo et al., 2015). The lymphoblastoid cell line used in this paper is a result of human B lymphocytes immortalized with the Epstein Barr virus, hence without tumor features and with intact apoptotic and mitotic machineries (Sugimoto et al., 2004;

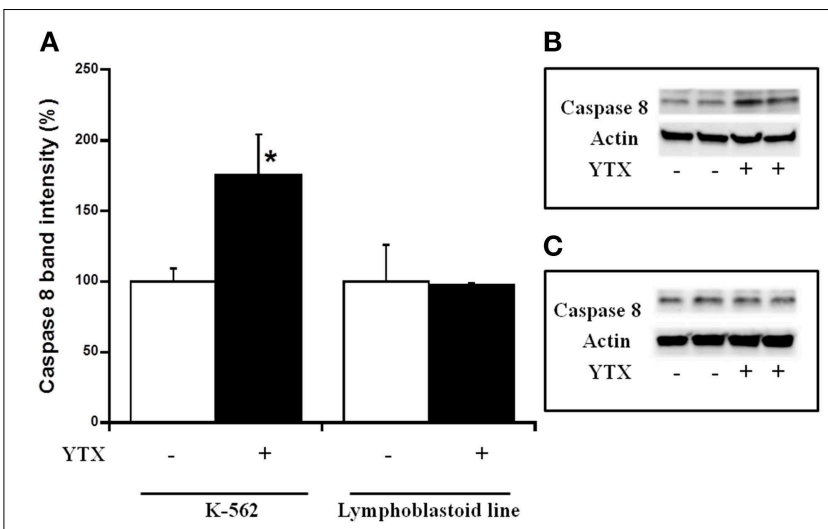

FIGURE 5 | Effect of YTX on cytosolic caspase 8 expression in K-562 and lymphoblastoid cell lines after $\mathbf{2 4} \mathbf{h}$ of incubation. Cells were incubated for $24 \mathrm{~h}$ with $30 \mathrm{nM}$ YTX $\left(37^{\circ} \mathrm{C}\right.$ and $5 \% \mathrm{CO}_{2}$ atmosphere). (A) Percentage of cytosolic caspase 8 levels in K-562 and lymphoblastoid cell lines after $24 \mathrm{~h}$ of YTX incubation. Mean \pm SEM of three experiments.

Cytosolic caspase 8 values were calculated respect to $\beta$-actin band intensity. $3 \times 10^{6}$ cells per condition were lysed and $20 \mu \mathrm{g}$ of total protein per condition was charged in the electrophoresis gel. *Significant differences between untreated and YTX-treated cells by ANOVA test. (B,C) Representative experiments of western blot band intensity of cytosolic caspase 8 in K-562 and lymphoblastoid cell lines after $24 \mathrm{~h}$ of treatment, respectively.

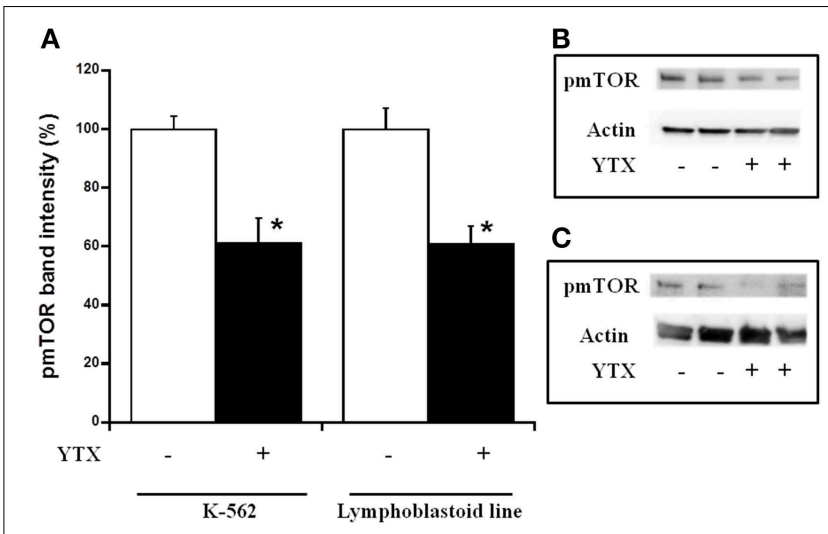

FIGURE 6 | Effect of YTX on cytosolic pmTOR expression in K-562 and lymphoblastoid cell lines after $\mathbf{4 8 h}$ of incubation. Cells were incubated for $48 \mathrm{~h}$ with $30 \mathrm{nM}$ YTX $\left(37^{\circ} \mathrm{C}\right.$ and $5 \% \mathrm{CO}_{2}$ atmosphere). (A) Percentage of cytosolic pmTOR levels in K-562 and lymphoblastoid cell lines after $48 \mathrm{~h}$ of YTX incubation. Mean \pm SEM of three experiments. Cytosolic pmTOR values were calculated respect to $\beta$-actin band intensity. $3 \times 10^{6}$ cells per condition were lysed and $20 \mu \mathrm{g}$ of total protein per condition was charged in the electrophoresis gel. *Significant differences between untreated and YTX-treated cells by ANOVA test. (B,C) Representative experiments of western blot band intensity of cytosolic pmTOR in K-562 and lymphoblastoid cell lines after $48 \mathrm{~h}$ of treatment, respectively.

Sie et al., 2009; Hussain and Mulherkar, 2012). Therefore, this line is a good tool to study the effects of the toxin in a non-tumor cellular model with mitotic ability to grow up (fresh cells do not have this property), and normal apoptotic machinery (tumor cells do not have it) (Sugimoto et al., 2004; Sie et al., 2009; Hussain and Mulherkar, 2012). 


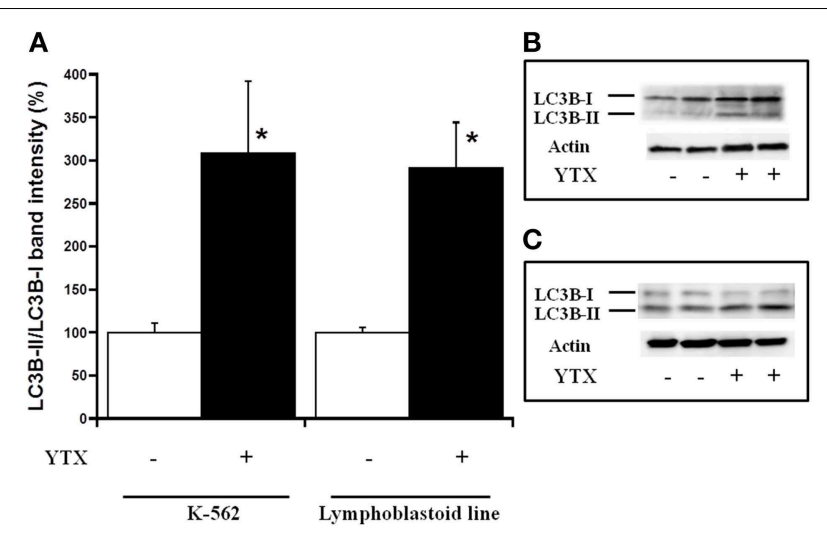

FIGURE 7 | Effect of YTX on cytosolic LC3B-II/LC3B-I expression in K-562 and lymphoblastoid cell lines after $\mathbf{4 8 h}$ of incubation. Cells were incubated for $48 \mathrm{~h}$ with $30 \mathrm{nM}$ YTX $\left(37^{\circ} \mathrm{C}\right.$ and $5 \% \mathrm{CO}_{2}$ atmosphere). (A) Percentage of cytosolic LC3B-II/LC3B-I levels in K-562 and lymphoblastoid cell lines after $48 \mathrm{~h}$ of YTX incubation. Mean \pm SEM of three experiments. Cytosolic LC3B-I and LC3B-II values were calculated respect to $\beta$-actin band intensity and the ratio between LC3B-II and LC3B-I was calculated in order to quantify the autophagosomal LC3B-II isotype $3 \times 10^{6}$ cells per condition were lysed and $20 \mu \mathrm{g}$ of total protein per condition was charged in the electrophoresis gel. *Significant differences between untreated and YTX-treated cells by ANOVA test. (B,C) Representative experiments of western blot band intensity of cytosolic LC3B-I and LC3B-II in K-562 and lymphoblastoid cell lines after $48 \mathrm{~h}$ of treatment, respectively.

The first difference observed between K-562 and lymphoblastoid lines was the effect of YTX on cell viability. Cellular proliferation is usually measured by MTT assay. This assay informs about the percentage of viable cells capable to reduce the MTT dye within the mitochondria (Mosmann, 1983; Loveland et al., 1992; Verma et al., 2010). The quantification of $\mathrm{LDH}$ release is a simple assay to know cell membrane integrity, since after the lysis of the cells, $\mathrm{LDH}$ is released to the extracellular medium and the released amount is proportional to the number of broken cells (Lobner, 2000). In this regard, the K-562 cell line did show a decrease in cell proliferation accompanied by an increase in LDH release after both 24 and $48 \mathrm{~h}$ of YTX incubation. That is, after YTX treatment the number of K-562 cells was decreasing because cell death was triggered, since apoptosis and autophagy activation was observed, the same as it was described in previous studies (Fernandez-Araujo et al., 2014; Fernández-Araujo et al., 2015). However, in the lymphoblastoid cell line, no effect in cell viability was observed in the first $24 \mathrm{~h}$ of treatment, and after $48 \mathrm{~h}$, cell proliferation was decreased without any LDH release, that is without cellular lysis. These results suggest no cell death activation but probably proliferation arrested in the lymphoblastoid line after a long term of YTX exposure. The decrease in the signal observed in MTT assay in the lymphoblastoid line after $48 \mathrm{~h}$ YTX treatment comparing with cells without treatment is due to a non-increase in the cell number in the same way than the control where the cells can proliferate. In addition at this time, an increase in the mitochondrial mass, studied by flow cytometry, was observed. In this sense, while the lymphoblastoid cell line usually duplicate its population in $24 \mathrm{~h}$ (Sie et al., 2009), YTX
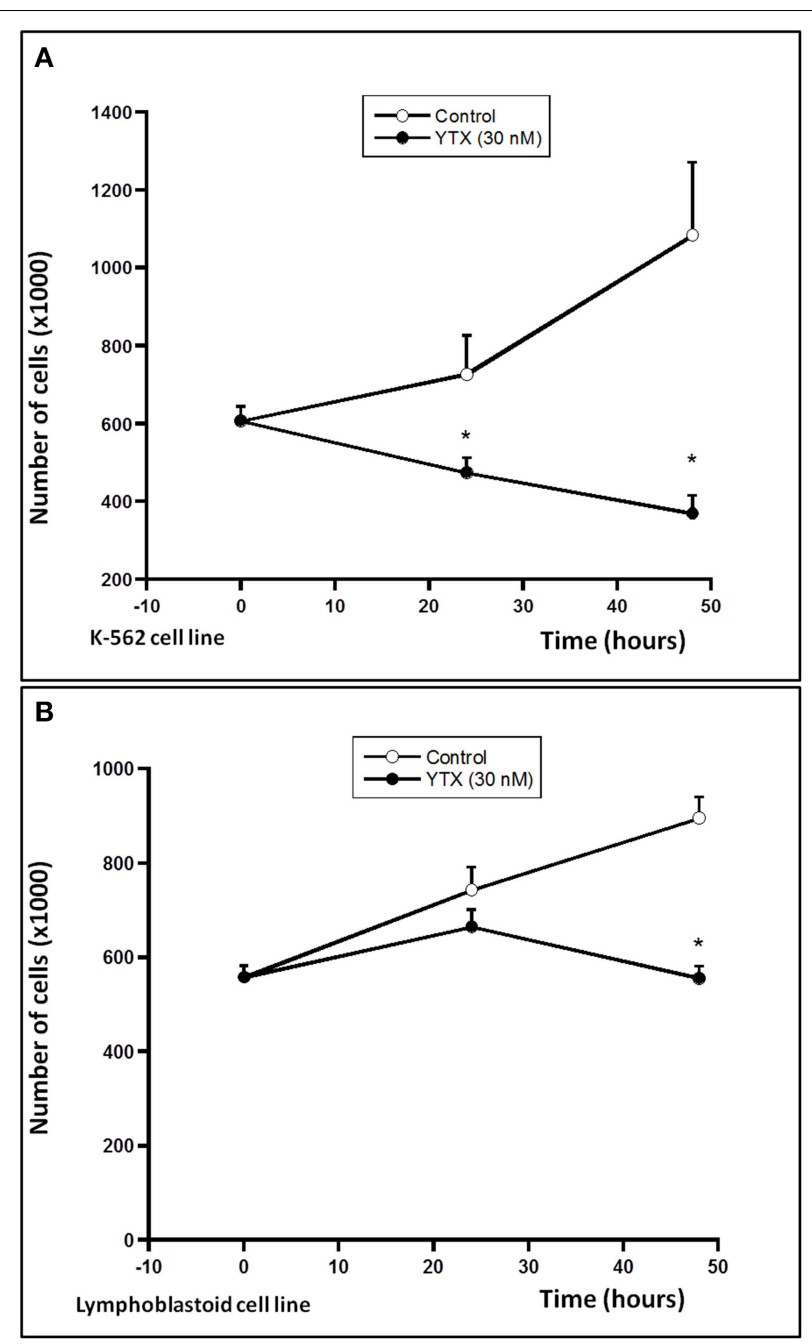

FIGURE 8 | Effect of YTX on cellular proliferation in K-562 and lymphoblastoid cell lines. Cells were incubated with $30 \mathrm{nM}$ YTX for 24 and $48 \mathrm{~h}\left(37^{\circ} \mathrm{C}\right.$ and $5 \% \mathrm{CO}_{2}$ atmosphere). Cells were counted with the Scepter ${ }^{\mathrm{TM}}$ Handheld automated cell counter and confirmed as final concentration of protein by Direct Detect ${ }^{\mathrm{TM}}$ and Bradford assay. (A) Number of K-562 cells after 24 and $48 \mathrm{~h}$ of YTX incubation. (B) Number of lymphoblastoid cells after 24 and $48 \mathrm{~h}$ of YTX incubation. Mean \pm SEM of four experiments. *Significant differences between untreated and YTX-treated cells in each case by ANOVA test.

could block this increase in the population without cell death activation.

Interesting, the increase in caspase 8 activity was previously observed in K-562 cell line after $24 \mathrm{~h}$ of YTX treatment (Fernandez-Araujo et al., 2014). In the present paper, the expression of the active form of caspase 8 is also observed in K562 cells. This active hallmark is typical from extrinsic apoptotic pathway, and has never been discussed after YTX incubation (Korsnes and Espenes, 2011; Korsnes, 2012; Fernandez-Araujo et al., 2014). In addition, the levels of cytochrome $\mathrm{c}$ demonstrate that YTX is also triggering the intrinsic apoptosis (Fulda and Debatin, 2006). Therefore, YTX activates both intrinsic and extrinsic apoptotic cell death. However, none of these hallmarks 
were observed in lymphoblastoid cells, showing different YTX effects depending on the cellular model, as it was previously pointed out (Tobío et al., 2012).

PDE4A is involved in the mechanism of action of YTX in the K-562 cell line (Fernandez-Araujo et al., 2014). However, after $24 \mathrm{~h}$ of YTX treatment, the levels of cytosolic PDE4A were not modified in the lymphoblastoid cell line, and at this time apoptotic hallmarks and cell viability were not modified either. Moreover, when PDE4A was studied by western blot, different molecular weights for both K-562 cell line and lymphoblastoid cells were observed. This fact can be relevant since any difference in the structure of the PDE4A protein could be a key point of the mechanism of action of YTX. The molecular structure of proteins is a critical parameter for the affinity or interaction between proteins and other molecules, as it was reported in previous studies (Funder et al., 1974; Yatime et al., 2011; Tubaro et al., 2014). These differences can lead to different YTX-PDE4A affinity or to different PDE4A functions depending on the PDE4A structure. In this sense, tumor cells have protein mutations that could lead to the change in the protein function, and these mutations can be used as tumor biomarkers (Wang et al., 2011). Therefore, the PDE4A on the K-562 cell line seems to be the specific and maybe a potential target to tumor therapies in this type of leukemia.

After $48 \mathrm{~h}$ of YTX treatment, lymphoblastoid cells showed similar features to those observed in the K-562 cell line (cytosolic PDE4A and pmTOR decrease and LC3B-II/LC3B-I ratio increase). However, these effects did not imply cell death in the lymphoblastoid cell line, as $\mathrm{LDH}$ results have shown. At this time, $48 \mathrm{~h}$ of YTX treatment, the autophagy activated in K-562 leads to cell death. However, in the lymphoblastoid cell line, autophagy pathway is activated, as the pmTOR and LC3BII/LC3B-I expression shows. Under unfavorable conditions cells develop mechanisms to start the digestion or recycling of different parts of the cell in order to obtain elements to survive

TABLE 1 | Summary of the viability, apoptotic and autophagic features of K-562 and lymphoblastoid cell line after YTX incubation studied in this paper.

\begin{tabular}{|c|c|c|c|c|}
\hline \multirow[t]{2}{*}{ Features } & \multicolumn{2}{|c|}{ K-562 tumor cell line } & \multicolumn{2}{|c|}{ Lymphoblastoid cell line } \\
\hline & $24 \mathrm{~h}$ & $48 \mathrm{~h}$ & $24 \mathrm{~h}$ & $48 \mathrm{~h}$ \\
\hline \multicolumn{5}{|l|}{ MTT viability } \\
\hline \multicolumn{5}{|l|}{$\mathrm{LDH}$ release } \\
\hline \multicolumn{5}{|l|}{ PDE4A expression } \\
\hline \multicolumn{5}{|l|}{ Mitochondrial mass } \\
\hline Cell death & YES & YES & NO & $\mathrm{NO}$ \\
\hline Apoptotic hallmarks & YES & NO & NO & NO \\
\hline Autophagic hallmarks & NO & YES & NO & YES \\
\hline \multicolumn{5}{|l|}{ Number of cells } \\
\hline & $\begin{array}{l}\text { Apoptosis } \\
\text { cell death }\end{array}$ & $\begin{array}{l}\text { Autophagic } \\
\text { cell death }\end{array}$ & No effect & $\begin{array}{l}\text { Cell proliferation } \\
\text { arrested } \\
\text { by autophagy } \\
\text { cell survive }\end{array}$ \\
\hline
\end{tabular}

under these critical conditions. Sometimes, the cell cannot survive to this process, and autophagic cell death is activated (Fulda, 2012). But in other times, the aim of the autophagy, which is to survive in extreme conditions, is performed (Hu et al., 2012). Contrary to the K-562 cell line, in lymphoblastoid cells, although autophagy is activated, cell death is not induced while a decrease in cell proliferation rate is observed. One possibility could be the activation of the autophagic survival mechanism through the cell growth regulator mTOR protein, the same as it was described after nutrient deprivation in different type of cells (Jung et al., 2010). A decrease in cell proliferation by autophagic activation was also observed in colon cells and in the human mammary epithelial cell line after treatment with rapamycin and hydrogen sulfide, respectively (Wu et al., 2012; Chen et al., 2013). Also, rapamycin has shown cell cycle arrest in G1 phase of the mitosis in endometrial carcinomas (BaeJump et al., 2010). Therefore, the activation of autophagy in the lymphoblastoid cell line leads to a proliferation rate arrest due to the YTX treatment. This theory is corroborated by the results shown in Figure 8, since K-562 cells number is decreased by YTX effect, while lymphoblastoid cells number is not modified after YTX incubation, suggesting cellular proliferation arrest by the toxin.

It was described that the point where cell proliferation, apoptosis, and autophagy converge are the mitochondria (Filippi-Chiela et al., 2011). Therefore, a close relationship between MPTP and autophagy or apoptosis was established (Lemasters et al., 1998). MPTP leads to mitochondrial membrane depolarization that finally induces the opening transition pore to release pro-apoptotic proteins to the cytosol (Weiss et al., 2003). When the MPTP process is activated only in some mitochondria, the autophagy is triggered, while apoptosis is activated when a high number of mitochondria have MPTP activation (Lemasters et al., 1998). But the exact linking mechanism between MPTP and autophagy is unknown (Elmore et al., 2001). In his work, after $48 \mathrm{~h}$ YTX treatment, when autophagic cell death is activated in the K-562 line, mitochondrial mass was decreased. In this context, mitophagy was defined as the mitochondrial autophagy to describe the mitochondrial removal, characteristic of autophagy activation (Youle and Narendra, 2011). On the other hand, after the incubation with YTX for $48 \mathrm{~h}$, the mitochondrial mass was increased in the lymphoblastoid cell line. Therefore, this is another hallmark to guarantee that the autophagic process activated after $48 \mathrm{~h}$ in the K-562 cell line is not occurring in the lymphoblastoid cell line. In the first case, the cells activate autophagy accompanied by mitophagy and mitochondrial signal decrease, while the lymphoblastoid cells could activate autophagy as a survival process accompanied by an increase of mitochondrial mass.

In conclusion, YTX modulates different pathways with different final result depending on the cellular model. In the tumor model, K-562 cells, the type II of programmed cell death is triggered after YTX treatment. While in a non-tumor model, the lymphoblastoid cell line, a survival autophagic process is activated after toxin incubation. Furthermore, apoptosis is only triggered in the tumor model, while in lymphoblastoid cell line, this type of cell death was not activated after YTX incubation. 
This fact could be interesting in order to study the potential effect of YTX in different anti-tumor therapeutics treatments. All these results are summarized in Table 1.

\section{Acknowledgments}

The research leading to these results has received funding from the following FEDER cofunded-grants. From CDTI and Technological Funds, supported by Ministerio de Economía

\section{References}

Alfonso, A., de la Rosa, L., Vieytes, M. R., Yasumoto, T., and Botana, L. M. (2003). Yessotoxin, a novel phycotoxin, activates phosphodiesterase activity. Effect of yessotoxin on cAMP levels in human lymphocytes. Biochem. Pharmacol. 65, 193-208. doi: 10.1016/S0006-2952(02)01454-5

Alfonso, A., Vieytes, M. R., Yasumoto, T., and Botana, L. M. (2004). A rapid microplate fluorescence method to detect yessotoxins based on their capacity to activate phosphodiesterases. Anal. Biochem. 326, 93-99. doi: 10.1016/j.ab.2003.11.022

Alfonso, C., Alfonso, A., Vieytes, M. R., Yasumoto, T., and Botana, L. M. (2005). Quantification of yessotoxin using the fluorescence polarization technique and study of the adequate extraction procedure. Anal. Biochem. 344, 266-274. doi: 10.1016/j.ab.2005.06.044

Asirvatham, A. L., Galligan, S. G., Schillace, R. V., Davey, M. P., Vasta, V., Beavo, J. A., et al. (2004). A-kinase anchoring proteins interact with phosphodiesterases in T lymphocyte cell lines. J. Immunol. 173, 4806-4814. doi: 10.4049/jimmunol.173.8.4806

Bae-Jump, V. L., Zhou, C., Boggess, J. F., Whang, Y. E., Barroilhet, L., and Gehrig, P. A. (2010). Rapamycin inhibits cell proliferation in type I and type II endometrial carcinomas: a search for biomarkers of sensitivity to treatment. Gynecol. Oncol. 119, 579-585. doi: 10.1016/j.ygyno.2010.08.025

Baillie, G. S., Scott, J. D., and Houslay, M. D. (2005). Compartmentalisation of phosphodiesterases and protein kinase A: opposites attract. FEBS Lett. 579, 3264-3270. doi: 10.1016/j.febslet.2005.03.089

Baserga, R. (1965). The relationship of the cell cycle to tumor growth and control of cell division: a review. Cancer Res. 25, 581-595.

Botana, L. M., Alfonso, A., Vieytes, M. R., Loza, M. I., and Inventors. (2011). Therapeutic use of Yessotoxins as Human Tumor Cell Growth Inhibitors. Patent No EP1875906 A3.

Carlucci, A., Lignitto, L., and Feliciello, A. (2008). Control of mitochondria dynamics and oxidative metabolism by cAMP, AKAPs and the proteasome. Trends Cell Biol. 18, 604-613. doi: 10.1016/j.tcb.2008.09.006

Chen, N., Eritja, N., Lock, R., and Debnath, J. (2013). Autophagy restricts proliferation driven by oncogenic phosphatidylinositol 3-kinase in three-dimensional culture. Oncogene 32, 2543-2554. doi: 10.1038/onc. 2012.277

Codogno, P., and Meijer, A. J. (2005). Autophagy and signaling: their role in cell survival and cell death. Cell Death Differ. 12, 1509-1518. doi: 10.1038/sj.cdd.4401751

Cuervo, A. M., Bergamini, E., Brunk, U. T., Droge, W., Ffrench, M., and Terman, A. (2005). Autophagy and aging: the importance of maintaining "clean" cells. Autophagy 1, 131-140. doi: 10.4161/auto.1.3.2017

Debatin, K. M., Poncet, D., and Kroemer, G. (2002). Chemotherapy: targeting the mitochondrial cell death pathway. Oncogene 21, 8786-8803. doi: 10.1038/sj.onc. 1206039

Elmore, S. (2007). Apoptosis: a review of programmed cell death. Toxicol. Pathol. 35, 495-516. doi: 10.1080/01926230701320337

Elmore, S. P., Qian, T., Grissom, S. F., and Lemasters, J. J. (2001). The mitochondrial permeability transition initiates autophagy in rat hepatocytes. FASEB J. 15, 2286-2287. doi: 10.1096/fj.01-0206fje y Competitividad, AGL2012-40185-CO2-01, AGL2014-58210$\mathrm{R}$, and Consellería de Cultura, Educación e Ordenación Universitaria, GRC2013-016, and through Axencia Galega de Innovación, Spain, ITC-20133020 SINTOX. From CDTI under ISIP Programme, Spain, IDI-20130304 APTAFOOD. From the European Union's Seventh Framework Programme managed by REA-Research Executive Agency (FP7/2007-2013) under grant agreement 312184 PHARMASEA. Andrea Fernández-Araujo was supported by a fellowship from Subprograma de Formación de Personal Investigador (AGL2009-13581-C02-01), Spain.

Fernández-Araujo, A., Alfonso, A., Vieytes, M. R., and Botana, L. M. (2015). Key role of phosphodiesterase $4 \mathrm{~A}$ (PDE4A) in autophagy triggered by yessotoxin. Toxicology 329, 60-72. doi: 10.1016/j.tox.2015.01.004

Fernandez-Araujo, A., Tobío, A., Alfonso, A., and Botana, L. M. (2014). Role of AKAP 149-PKA-PDE4A complex in cell survival and cell differentiation processes. Int. J. Biochem. Cell Biol. 53, 89-101. doi: 10.1016/j.biocel.2014.04.028

Filippi-Chiela, E. C., Villodre, E. S., Zamin, L. L., and Lenz, G. (2011) Autophagy interplay with apoptosis and cell cycle regulation in the growth inhibiting effect of resveratrol in glioma cells. PLOS ONE 6:e20849. doi: 10.1371/journal.pone.0020849

Fulda, S. (2012). Autophagy and cell death. Autophagy 8, 1250-1251. doi: 10.4161/auto.20669

Fulda, S., and Debatin, K. M. (2006). Extrinsic versus intrinsic apoptosis pathways in anticancer chemotherapy. Oncogene 25, 4798-4811. doi: 10.1038/sj.onc. 1209608

Funder, J. W., Feldman, D., Highland, E., and Edelman, I. S. (1974). Molecular modifications of anti-aldosterone compounds: effects on affinity of spirolactones for renal aldosterone receptors. Biochem. Pharmacol. 23, 1493-1501. doi: 10.1016/0006-2952(74)90386-4

Hu, Y. L., DeLay, M., Jahangiri, A., Molinaro, A. M., Rose, S. D., Carbonell, W. S., et al. (2012). Hypoxia-induced autophagy promotes tumor cell survival and adaptation to antiangiogenic treatment in glioblastoma. Cancer Res. 72, 1773-1783. doi: 10.1158/0008-5472.CAN-11-3831

Hussain, T., and Mulherkar, R. (2012). Lymphoblastoid cell lines: a continuous in vitro source of cells to study carcinogen sensitivity and DNA repair. Int. J. Mol. Cell. Med. 1, 75-87.

Javadov, S., and Karmazyn, M. (2007). Mitochondrial permeability transition pore opening as an endpoint to initiate cell death and as a putative target for cardioprotection. Cell. Physiol. Biochem. 20, 1-22. doi: 10.1159/0001 03747

Jung, C. H., Ro, S. H., Cao, J., Otto, N. M., and Kim, D. H. (2010). mTOR regulation of autophagy. FEBS Lett. 584, 1287-1295. doi: 10.1016/j.febslet.2010.01.017

Klionsky, D. J., and Emr, S. D. (2000). Autophagy as a regulated pathway of cellular degradation. Science 290, 1717-1721. doi: 10.1126/science.290.5497.1717

Korsnes, M., and Espenes, A. (2011). Yessotoxin as an apoptotic inducer. Toxicon 57, 947-958. doi: 10.1016/j.toxicon.2011.03.012

Korsnes, M. S. (2012). Yessotoxin as a tool to study induction of multiple cell death pathways. Toxins 4, 568-579. doi: 10.3390/toxins 4070568

Lazova, R., Camp, R. L., Klump, V., Siddiqui, S. F., Amaravadi, R. K., and Pawelek, J. M. (2012). Punctate LC3B expression is a common feature of solid tumors and associated with proliferation, metastasis, and poor outcome. Clin. Cancer Res. 18, 370-379. doi: 10.1158/1078-0432.CCR-1 $1-1282$

Lemasters, J. J., Nieminen, A. L., Qian, T., Trost, L. C., Elmore, S. P., Nishimura, Y., et al. (1998). The mitochondrial permeability transition in cell death: a common mechanism in necrosis, apoptosis and autophagy. Biochim. Biophys. Acta 1366, 177-196. doi: 10.1016/S0005-2728(98)00112-1

Lobner, D. (2000). Comparison of the LDH and MTT assays for quantifying cell death: validity for neuronal apoptosis? J. Neurosci. Methods 96, 147-152. doi: 10.1016/S0165-0270(99)00193-4 
Loveland, B. E., Johns, T. G., Mackay, I. R., Vaillant, F., Wang, Z. X., and Hertzog, P. J. (1992). Validation of the MTT dye assay for enumeration of cells in proliferative and antiproliferative assays. Biochem. Int. 27, 501-510.

Mosmann, T. (1983). Rapid colorimetric assay for cellular growth and survival: application to proliferation and cytotoxicity assays. J. Immunol. Methods 65, 55-63. doi: 10.1016/0022-1759(83)90303-4

Murata, M., Kumagai, M., Lee, J. S., and Yasumoto, T. (1987). Isolation and structure of yessotoxin, a novel polyether compound implicated in diarrhetic shellfish poisoning. Tetrahedron Lett. 28, 5869-5872. doi: 10.1016/S00404039(01)81076-5

Ouyang, L., Shi, Z., Zhao, S., Wang, F. T., Zhou, T. T., Liu, B., et al. (2012). Programmed cell death pathways in cancer: a review of apoptosis, autophagy and programmed necrosis. Cell Prolif. 45, 487-498. doi: 10.1111/j.13652184.2012.00845.x

Paz, B., Riobó, P., Fernández, M. L., Fraga, S., and Franco, J. M. (2004). Production and release of yessotoxins by the dinoflagellates Protoceratium reticulatum and Lingulodinium polyedrum in culture. Toxicon 44, 251-258. doi: $10.1016 /$ j.toxicon.2004.05.021

Pazos, M. J., Alfonso, A., Vieytes, M. R., Yasumoto, T., and Botana, L. M. (2006). Study of the interaction between different phosphodiesterases and yessotoxin using a resonant mirror biosensor. Chem. Res. Toxicol. 19, 794-800. doi: $10.1021 / \mathrm{tx} 0503303$

Rhodes, L., McNabb, P., de Salas, M., Briggs, L., Beuzenberg, V., and Gladstone, M. (2006). Yessotoxin production by Gonyaulax spinifera. Harmful Algae 5, 148-155. doi: 10.1016/j.hal.2005.06.008

Sample, V., DiPilato, L. M., Yang, J. H., Ni, Q., Saucerman, J. J., and Zhang, J. (2012). Regulation of nuclear PKA revealed by spatiotemporal manipulation of cyclic AMP. Nat. Chem. Biol. 8, 375-382. doi: 10.1038/nchem bio.799

Satake, M., MacKenzie, L., and Yasumoto, T. (1997). Identification of Protoceratium reticulatum as the biogenetic origin of yessotoxin. Nat. Toxins 5, 164-167. doi: 10.1002/19970504NT7

Sie, L., Loong, S., and Tan, E. K. (2009). Utility of lymphoblastoid cell lines. J. Neurosci. Res. 87, 1953-1959. doi: 10.1002/jnr.22000

Stern, S. T., Adiseshaiah, P. P., and Crist, R. M. (2012). Autophagy and lysosomal dysfunction as emerging mechanisms of nanomaterial toxicity. Part. Fibre Toxicol. 9, 20. doi: 10.1186/1743-8977-9-20

Sugimoto, M., Tahara, H., Ide, T., and Furuichi, Y. (2004). Steps involved in immortalization and tumorigenesis in human B-lymphoblastoid cell lines transformed by Epstein-Barr virus. Cancer Res. 64, 3361-3364. doi: 10.1158/0008-5472.CAN-04-0079

Tobío, A., Fernández-Araujo, A., Alfonso, A., and Botana, L. M. (2012). Role of yessotoxin in calcium and cAMP-crosstalks in primary and K-562 human lymphocytes: the effect is mediated by Anchor kinase a mitochondrial proteins. J. Cell. Biochem. 113, 3752-3761. doi: 10.1002/jcb.24249

Tsujimoto, Y., and Shimizu, S. (2005). Another way to die: autophagic programmed cell death. Cell Death Differ. 12, 1528-1534. doi: 10.1038/sj.cdd.4401777

Tubaro, A., del Favero, G., Pelin, M., Bignami, G., and Poli, M. (2014). "Palytoxin and analogues: biological effects and detection," in Seafood and Freshwater Toxins: Pharmacology, Physiology, and Detection, ed L. M. Botana (Boca Raton, FL: CRC Press), 741-772. doi: 10.1201/b16662-30

Verma, A., Prasad, K. N., Singh, A. K., Nyati, K. K., Gupta, R. K., and Paliwal, V. K. (2010). Evaluation of the MTT lymphocyte proliferation assay for the diagnosis of neurocysticercosis. J. Microbiol. Methods 81, 175-178. doi: 10.1016/j.mimet.2010.03.001

Wang, Q., Chaerkady, R., Wu, J., Hwang, H. J., Papadopoulos, N., Kopelovich, L., et al. (2011). Mutant proteins as cancer-specific biomarkers. Proc. Natl. Acad. Sci. U.S.A. 108, 2444-2449. doi: 10.1073/pnas.1019203108

Weiss, J. N., Korge, P., Honda, H. M., and Ping, P. (2003). Role of the mitochondrial permeability transition in myocardial disease. Circ. Res. 93, 292-301. doi: 10.1161/01.RES.0000087542.26971.D4

Wu, J., Dang, Y., Su, W., Liu, C., Ma, H., Shan, Y., et al. (2006). Molecular cloning and characterization of rat LC3A and LC3B-Two novel markers of autophagosome. Biochem. Biophys. Res. Commun. 339, 437-442. doi: 10.1016/j.bbrc.2005.10.211

Wu, Y. C., Wang, X. J., Yu, L., Chan, F. K. L., Cheng, A. S. L., Yu, J., et al. (2012). Hydrogen sulfide lowers proliferation and induces protective autophagy in colon epithelial cells. PLoS ONE 7:e37572. doi: 10.1371/journal.pone.0037572

Yatime, L., Laursen, M., Morth, J. P., Esmann, M., Nissen, P., and Fedosova, N. U. (2011). Structural insights into the high affinity binding of cardiotonic steroids to the Na+,K+-ATPase. J. Struct. Biol. 174, 296-306. doi 10.1016/j.jsb.2010.12.004

Youle, R. J., and Narendra, D. P. (2011). Mechanisms of mitophagy. Nat. Rev. Mol. Cell Biol. 12, 9-14. doi: 10.1038/nrm3028

Conflict of Interest Statement: The authors declare that the research was conducted in the absence of any commercial or financial relationships that could be construed as a potential conflict of interest.

Copyright () 2015 Fernández-Araujo, Sánchez, Alfonso, Vieytes and Botana. This is an open-access article distributed under the terms of the Creative Commons Attribution License (CC BY). The use, distribution or reproduction in other forums is permitted, provided the original author(s) or licensor are credited and that the original publication in this journal is cited, in accordance with accepted academic practice. No use, distribution or reproduction is permitted which does not comply with these terms. 